\title{
GIS Project Environmental Framework for the Territory of South-Minusinsk Basin as a Tool for the Organization of Rational Use of Nature and Landscape Protection
}

\author{
Ekaterina V. Pavlova*a, \\ Marina L. Makhrova ${ }^{a}$ and Galina Yu. Yamskikh ${ }^{b}$ \\ ${ }^{a}$ Khakass State University N.F. Katanov \\ 92 Lenin Ave., Abakan, 655017, Russia \\ ${ }^{b}$ Siberian Federal University \\ 79 Svobodny, Krasnoyarsk, 660041, Russia
}

Received 02.03.2015, received in revised form 26.05.2015, accepted 17.06.2015

Developed GIS project local territorial coverage «Ecological framework of South-Minusinsk basin». The idea of its creation is a complex, historical, geographical and systematic approach to the processing and display of information on the nature, economy and population of SouthMinusinsk basin, which are two subjects of the Federation. The proposed structure of the GIS project will provide controls and environmental management tools for establishing monitoring systems prevent excessive anthropogenic pressures on the landscape, their conservation and sustainable natural resource management.

Keywords: South-Minusinsk basin, geographic information systems, ecological framework, large areal, linear and point elements and buffer zones, site remediation and restoration of nature.

DOI: 10.17516/1999-494X-2015-8-6-706-714.

(C) Siberian Federal University. All rights reserved

* Corresponding author E-mail address: eve21@yandex.ru 


\title{
ГИС-проект экологического каркаса территории
}

\section{Южно-Минусинской котловины}

как инструмент организации

\section{рационального природопользования \\ и сохранения ландшафтов}

\author{
Е.В. Павлова ${ }^{a}$, М.Л. Махрова ${ }^{a}$, Г.Ю. Ямских ${ }^{6}$

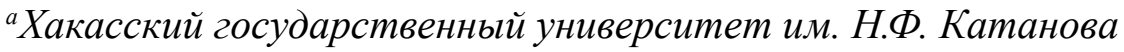 \\ Россия, 655017, Хакасия, Абакан, пр. Ленина, 92 \\ ${ }^{6}$ Сибирский федеральный университет \\ Россия, 660041, Красноярск, пр. Свободный, 79
}

Разработан ГИС-проект локального территориального охвата «Экологический каркас Южно-Минусинской котловиныр». Идея его создания заключается в комплексном историкогеографическом и системном подходе обработки и отображения информации о природе, хозяйстве и населении Южно-Минусинской котловины, на территории которой расположень два субъекта Федерачии. Предлагаемая структура ГИС-проекта обеспечит органь управления и природопользования инструментарием для налаживания системы мониторинга, предотвращения чрезмерной антропогенной нагрузки на ландшафт, его сохранения и рационального природопользования.

Ключевые слова: Южно-Минусинская котловина, географические информационные системы, экологический каркас, крупноареальные, линейные, точечные элементы и буферные зоны, территории рекультивачии и восстановления природы.

\section{Введение}

Производственная, сельскохозяйственная или природоохранная деятельность человека осуществляются в границах целостных природных образований - ландшафтов.

На территории левобережья Южно-Минусинской котловины наиболее активное влияние на ландшафт оказывает угольная промышленность. Систематическое освоение каменноугольных месторождений начинается с 30-х гг. ХХ в. На текущий момент активно разрабатываются открытым способом угольные месторождения Восточно-Бейского и Изыхского разрезов, а также разреза «Степной» и «Черногорский». В начале XXI в. стали разрабатываться два новых разреза - «Аршановский» и «Белоярский» [1]. Современное состояние природной среды характеризуется наложением двух процессов - естественного саморазвития ландшафтов и воздействия человека на современные природные процессы [2].

В связи с обширными преобразованиями природных ландшафтов в антропогенные ландшафты на территории Южно-Минусинской котловины появилась необходимость в мониторинге, в рамках которого должно осуществляться систематическое наблюдение и прогнозирование изменений структуры ландшафтов, а также их сохранение и рациональное природопользование. Решением поставленной проблемы может стать экологический каркас территории, который может послужить источником базы данных для наблюдения за территорией. 
Экологический каркас - это территориальная компенсационная система, состоящая из непрерывной сети участков с различным режимом природопользования и выступающая компромиссом между природным и демоэкономическим каркасами. Проектирование экологического каркаса должно производиться на основе всех необходимых знаний и достижений в областях сельского, водного, лесного хозяйства и других отраслей природопользования, управления территориями и системного анализа, различных сфер экологии [3].

Формирование экологического каркаса возможно посредством географической информационной системы (ГИС), так как любая ГИС способна обрабатывать большой массив однородной пространственно-координированной информации, поддерживать различные форматы баз данных, осуществлять диалоговый режим с пользователем, быстро настраиваться для решения широкого круга географических и социально-экономических задач пользователя, моделировать и визуализировать различные геоэкологические ситуации.

Целью нашего исследования является разработка ГИС-проекта «Экологический каркас территории Южно-Минусинской котловины» для поддержания на территории экологической стабильности и рационального природопользования. В ходе реализации цели решались следующие задачи: выделить элементы в структуре ГИС-проекта; определить содержание данных о пространственных объектах в форме их цифровых представлений; осуществить поиск, подбор, каталогизацию и получение исходных данных; спроектировать геопространственную базу данных и оцифровать данные.

\section{Материалы и методы}

За топографическую основу были взяты общегеографические карты масштаба 1:200000 (1980, 1991 гг.). Границы ландшафтов были оцифрованы по: ландшафтно-геморфологической карте Южно-Минусинской котловины (Альтер, 1974), карте агроприродного потенциала Минусинской котловины 1:500000 (Лысанова, 2000), ландшафтной карте Республики Хакасия 1:1500000 (Булатов, 2008). Перечисленные бумажные носители были отсканированы и переведены в растровый формат JPG. Границы особо охраняемых природных территорий были векторизованы на основе растровых карт: Республики Хакасия 1:2000000 (2001 г.) 1:500000 (2002, 2009, 2011 гг.), южной части Красноярского края 1:3000000 (2001 г.), заказника Кебежский 1:100000 км, особо охраняемых территорий и объектов Шушенского района 1:100 000 (2009 г). Лесные массивы были обозначены по лесным картам-схемам Ермаковского района 1:500000 (по материалам лесоустройства 1995 г., 1998 г.) и Каратузского района 1:500000 (по материалам лесоустройства, 1983 г). Категории земель были оцифрованы по схемам землепользования административных районов и схемам территориального планирования 2009 г.: Республики Хакасия (1:500000), ее административных районов - Алтайского (1:50000), Таштыпского, Аскизского, Бейского, Усть-Абаканского 1:100000 - и административных районов Красноярского края - Курагинского 1:100000, Шушенского районов 1:100000, Краснотуранского района 1:100000, Минусинского 1:50000, Ермаковского 1:50000. В том числе использовались: базовые карты облачной инфраструктуры ArcGIS Online, публичная кадастровая карта в виде карт местности масштабов от 1:1000000 до 1:100000.

Для решения поставленных в рамках исследования задач при обработке материалов применялся программный пакет ESRI ArcGIS 10.1, имеющий в своей структуре дополнительные 
модули анализа данных и собственную систему управления базами данных, позволившую сформировать геореляционную модель базы данных и спроектировать ГИС-проект «Экологический каркас территории Южно-Минусинской котловины». Картографические материалы были спроецированы на систему координат Pulkovo 1942 GK (Gauss Kruger) по опорным точкам с использованием полиномиальной трансформации. На основании того, что мы относим территорию экологического каркаса к региональному уровню, в ГИС-проекте был выбран базовый масштаб 1:500000.

Для более подробной характеристики района исследования проанализирована динамика площадей агроландшафтов в границах Южно-Минусинской котловины по сведениям о наличии земель у предприятий, организаций, хозяйств, обществ, занимающихся сельскохозяйственным производством, министерства сельского хозяйства Республики Хакасия и Красноярского края за 2002- 2014 гг.

Наибольшее влияние на окружающую среду оказывают городские населенные пункты; чем крупнее город, тем значительнее его техническое загрязнение, поэтому очень важно знать плотность населения [3]. Для выявления плотности населения были проанализированы и внесены в ГИС-проект данные Федеральной службы государственной статистики Росстат по численности населения Российской Федерации по муниципальным образованиям на 1 января 2014 г.

В результате анализа постановлений правительств Республики Хакасия и Красноярского края - об образовании особо охраняемой природной территории регионального значения; об утверждении схем развития и размещения особо охраняемых природных территорий Республики Хакасия и Красноярского края; схем территориального планирования муниципальных районов, расположенных на территории Южно-Минусинской котловины, - были определены и оцифрованы границы действующих и планируемых особо охраняемых территории.

В базе данных ГИС-проекта существуют различные виды информации: картографическая (графическая), атрибутивная и методанные (описательная).

Структура атрибутивных таблиц отражает сущность объектов, их тип геометрии (площадная, линейная или точечная) и другие параметры. Содержание каждой атрибутивной таблицы зависит от свойств географического объекта, ячейки полей должны быть заполнены информацией, которой будет достаточно для эффективного использования данных.

Атрибутивные данные всех слоев содержат обязательные поля OBJECTID (идентификатор объекта), SHAPE_Length и SHAPE_Area (информация о геометрии объектов). Каждую атрибутивную таблицу в базе геоданных возможно экспортировать в общедоступный формат файла с расширением XLS, что позволяет упростить работу с данными.

На основе атрибутивной информации в базе данных ГИС формируются алгоритмы SQLзапросов. Они дают возможность получения пространственной характеристики состояния ландшафтов и прогнозирование их дальнейшего состояния, а также позволяют решать следующие задачи в СУБД ArcGis: создание колонки, в которой с калькулятором поля (Field Calculator) можно выполнять сложные вычисления с помощью блоков кодов VBScript или Python, обрабатывающих данные перед вычислениями. К примеру, плотность населения из имеющихся в атрибутивной таблице площади населенных пунктов и численности населения в нем.

$$
-709-
$$


Используемое программное обеспечение позволяет разделять информацию на карте в логические категории, называемые картографическими слоями. Данные разделяются на слои карты так, что ими можно манипулировать и анализировать в пространстве либо по отдельности, либо совместно с другими слоями.

\section{Результаты}

После проецирования и привязки растровых изображений картографическая информация в проекте была сформирована в 11 традиционных векторных картографических слоев (населенные пункты, реки, автодороги, железные дороги и т.д.) и 8 тематических - крупноареальные элементы (ядра), линейные (транзитные территории), точечные, буферные территории (четыре слоя) и территории рекультивации и восстановления. При создании компоновки карты для некоторых слоев (населенные пункты, реки) надпись объектов была конвертирована в аннотации, что позволило упростить работу с картой.

Ландшафтно-геоморфологический слой без оверлея позволяет скомпоновать 6 карт. В атрибутивных данных слоя содержатся 42 вида ландшафта, составляющих 106 объектов, 6 поясов и подпоясов растительности. Виды ландшафтов расположены на максимальных высотах от 270-290 до 950-1100 м, для которых имеется 39 уникальных значений почвы, 13 генетических поверхностей (типов, видов), характеризующиеся различными генетическими процессами (рис. 1).

Слой изолиний представлен 561 объектом, значение которых варьирует от 300 до $1600 \mathrm{c}$ шагом в 100 м. Набор классов «Водные объекты» включает в себя 3 слоя и аннотации к ним. В слое «Озера» оцифровано 86 объектов, занимающих по площади 78,5 км², расположенных на территории Южно-Минусинской котловины (рис. 2а). Красноярское водохранилище занимает $2 \%\left(421,9\right.$ км$\left.^{2}\right)$ от всей площади территории. Слой «Водотоки» содержит 465 объектов протяженностью 45181 км, из которых 64 имеют уникальные значения в поле «Название»; в классификации по типу они разделяются на временные водотоки (47 объектов), оросительные каналы (93 объекта) и реки (290 объектов). Слой «Объекты культурного наследия» включает в себя 405 археологических памятников, из которых 8 федерального значения (Салбыкский курган),

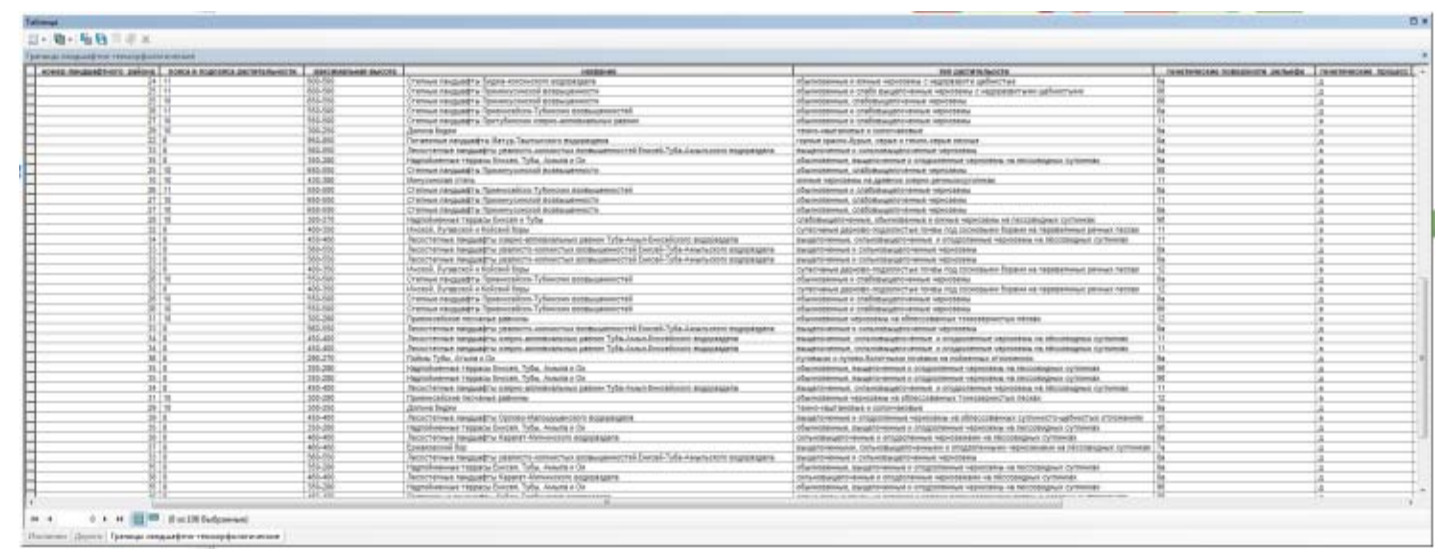

Рис. 1. Атрибутивная таблица ландшафтно-геоморфологического слоя 
а другие - регионального (рис. 2б). Слой «Дороги» состоит из 564 объектов, скомпонованных в 7 типов дорожного полотна (железные, автомобильные: шоссейные, магистральные, второстепенные, улучшенные грунтовые, грунтовые проселочные, полевые или лесные), суммарная протяженность которого составляет 6528 км (рис. 2в). Слой «Тип земель» имеет 6 классов значений: земли запаса, леса (эксплуатационные леса, леса, расположенные в лесостепной зоне с возможностью использования в сельском хозяйстве), сельскохозяйственные территории (в том числе земли перспективного сельского хозяйства), особо охраняемые природные территории. Слой содержит 26 объектов общей площадью 1014,3 км² (рис. 2г). Площадной слой «Населенный пункты» содержит 279 объектов, проклассифицированных по четырем классам (города, поселки, села, деревни и аалы), занимающих площадь 455,4 км² с численностью населения 655431 чел.

Тематические векторные слои экологического каркаса (ядра и точечные элементы) сформированы на основе существующей базы данных и дополняются транзитными слоями, буферными территориями и территориями рекультивации и восстановления.

«Ядра» экологического каркаса выполняют средозащитно-санитарную роль, являются территориями с заповедным режимом использования и территориям с регламентированным использованием (памятники природы, природные парки, заказники, памятники природы, национальный парк). В пределах Южно-Минусинской котловины ядрами выступают два участка

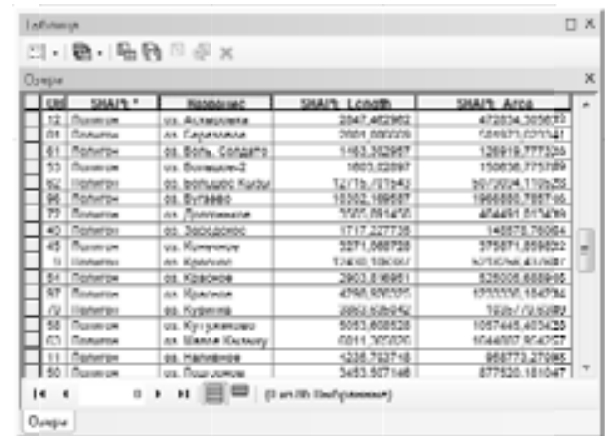

a

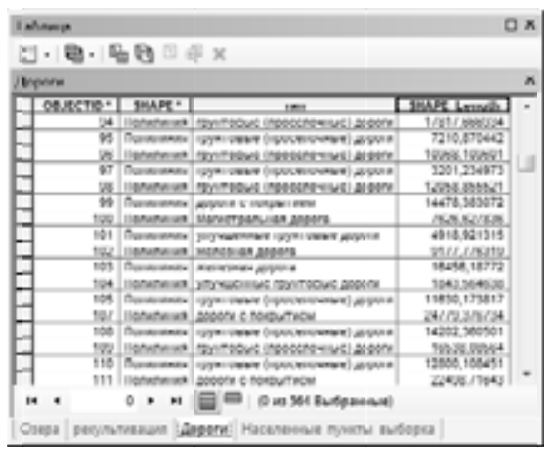

B

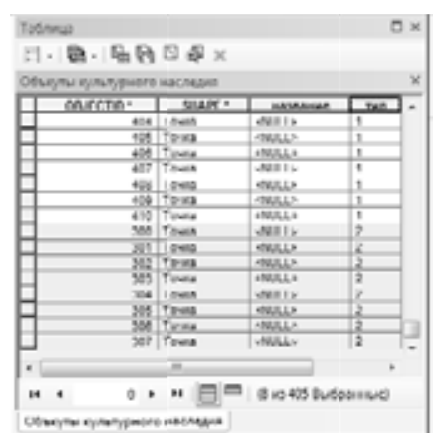

б

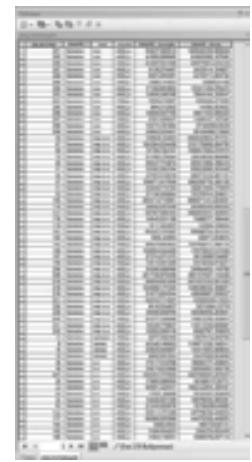

$\Gamma$

Рис. 2. Атрибутивная таблица слоев: а - озера; б - объекты культурного наследия; в - дороги; г - типы земель 
государственного природного заповедника «Хакасский», четыре памятника природы регионального значения, один проектируемый памятник природы и др. (рис. 3).

«Точечные элементы» экологического каркаса, сохраняющие отдельные уникальные объекты природы, не превышающие 10 км²$^{2}$, представлены тремя памятниками природы: гидрологическим, ботаническим, комплексным и культурно-историческими объектами.

«Экологические коридоры» являются наиболее сложными элементами каркаса, они осуществляют связь между ядерными элементами и поддерживают экологическую стабильность территории. К ним отнесены: крупные и мелкие речные долины; временные водотоки оросительных каналов и пересыхающие русла рек всей территории; водоохранные леса (общей пло-

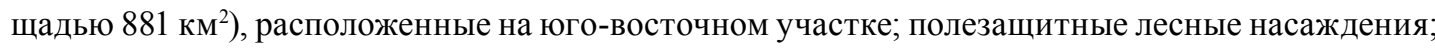
миграционные пути (водно-болотные, озерные комплексы, лесозащитные насаждения, места обитания исчезающих видов), функционирование которых обеспечивает Госкомитет по охране животного мира и окружающей среды Республики Хакасия.

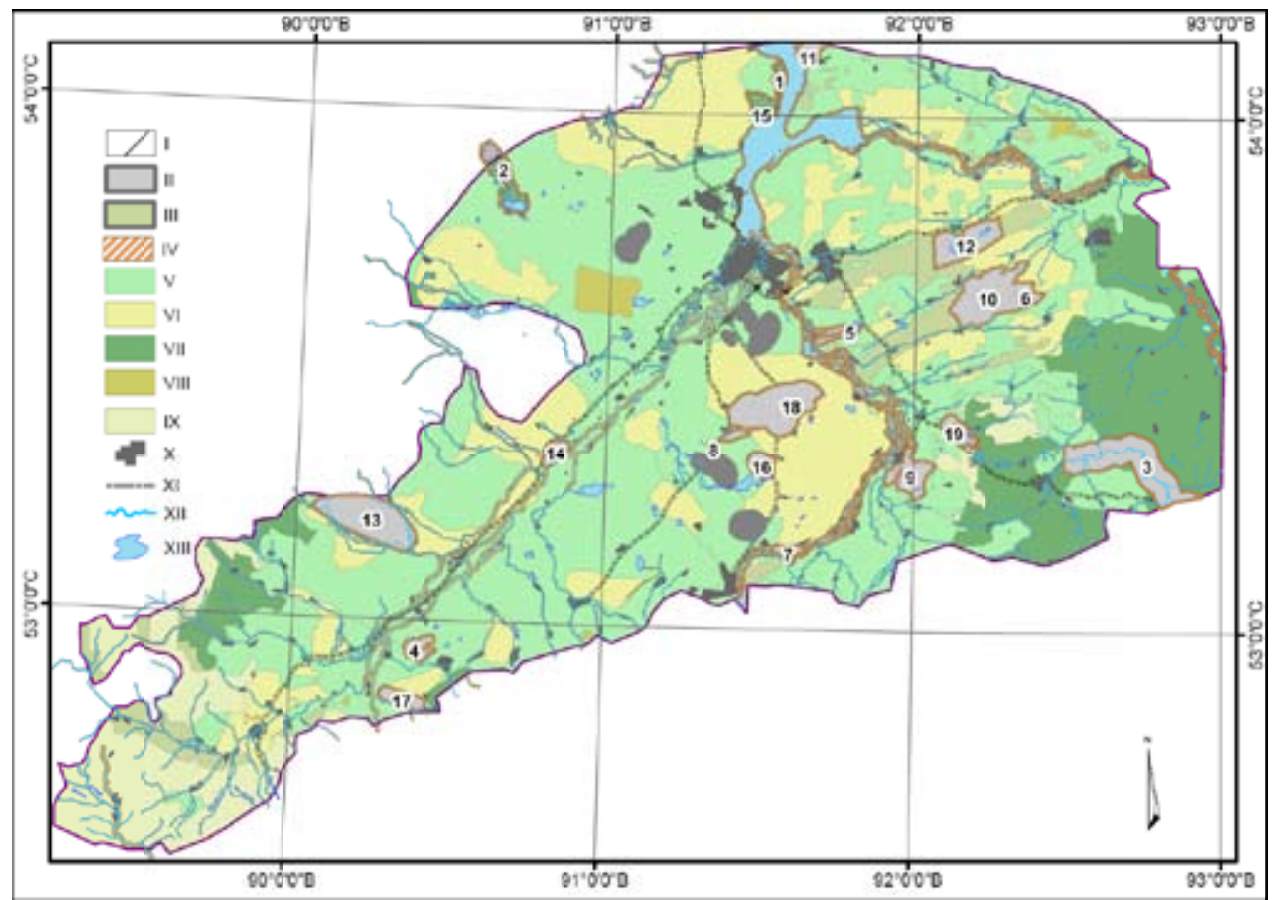

Рис. 3. Экологический каркас Южно-Минусинской котловины (масштаб 1:500000). Условные обозначения: I - заповедники; II - территории регламентированного природопользования, III - защитные леса, IV - буферные зоны; территории щадящего природопользования: V - сельскохозяйственные земли, VI - земли перспективного сельского хозяйства, VII - леса, расположенные в лесостепи, VIII - земли запаса, IX - эксплуатационные леса; X - территории интенсивного природопользования; XI - транзитные территории: XII - реки, XIII - озера. Действующие особо охраняемые природные территории: государственноый природный заповедник «Хакасский»: 1 - участок «Оглахты», 2 - участок «Камызякская степь с оз. Улугколь»; 3 - заказник Кебежский; памятники природы: 4 - Бондоревский бор, 5 - Кривинский бор, 6 - Лугавский бор, 7 - Очурский бор, 8 - Смирновский бор, 9 - Шушенский бор, участок - 2, р. Шушь; планируемые: заказники 10 - Лугавский бор, 11 - Краснотуранский бор, 12 - Минусинский бор, 16 - урочище «Трехозерки»; 13 - национальный парк Казановка, 15 - древняя крепость г. Куня; памятники природы 14 - Уйтаг, 17 - Большой Монок, 18 - оз. Куринка, 19 - Ойское болото 
Защиту ядер и транзитных территорий от неблагоприятных внешних воздействий осуществляют «буферные территории», к которым относятся санитарно-защитные зоны озер, рек, водохранилищ, особо охраняемых территорий, промышленных предприятий и земель лесного фонда $\left(1416,1 \mathrm{\kappa м}^{2}\right)$.

«Территории рекультивации и восстановления» представлены полигонами карьерных выработок, промышленных предприятий и населенными пунктами, а общая площадь достигает $676,1 \mathrm{\kappa м}^{2}$.

\section{Обсуждение результатов}

Проектирование экологического каркаса предполагает наряду с определением функции каждого элемента исходя из его роли в поддержании экологической стабильности ещё и установление соответствующего правового режима его использования на основе Федерального закона «Об охране окружающей среды», Земельного и Градостроительного кодексов и т.д. [3].

В ГИС-проекте к территориям с жестким (заповедным) режимом природопользования отнесены нетронутые антропогенным воздействием земли государственного природного заповедника «Хакасский», составляющие лишь 0,3 \% от всей площади территории исследования.

Территории с менее жестким регламентированным режимом природопользования занимают 14 \% от площади каркаса, и к ним относятся: водоохранные зоны (водохранилищ, рек, озер, водозаборов), санитарно-защитные зоны особо охраняемых территорий, промышленных предприятий, горных выработок, земель лесного фонда, зоны санитарной охраны лечебнооздоровительных местностей и курортов; участки земель запаса.

Территориями щадящего режима природопользования являются леса, расположенные в лесостепях и степях на юго-восточной окраине правобережной части котловины, в пределах которых возможно использование отдельных участков в сельском хозяйстве; сельхозугодия. Населенные пункты, места разработок полезных ископаемых, промышленные и транспортные объекты отнесены к территориям интенсивного природопользования.

Как показывает наработанный опыт создания экологических каркасов, чаще всего они формируется в административных границах (г. Солнечная Долина, г. Казань, г. Ярославль, Кирово-Чепецкий муниципальный район, Алтайский край, Астраханская, Белгородская, Брянская, Курганская, Калужская, Липецкая, Орловская и Псковская области). Это объясняется возможностью анализа доступной статистической отчетности по земельным ресурсам и экологическому состоянию территории. Реже встречаются региональные каркасы, выделяемые на основе ландшафтного или ландшафтно-географического анализа (Центр Русской равнины, Волго-Вятский регион и Нижнее Поволжье, бассейн р. Хилок и оз. Байкал, Обь-Томское междуречье), т.е. территориальные природные комплексы различного иерархического уровня. В наших исследованиях была предпринята попытка формирования экологического каркаса региона Южно-Минусинской котловины. Выбор территории исследования основывался на общности: тектонического и геологического строения, климатических характеристик, истории освоения и расселения населения, принадлежности к единой административной единице продолжительное время.

Так как мы под экологическим каркасом понимаем систему объектов и территорий с различным режимом природопользования, то в его структуре нами выделены две составляющие - 
природная и социально-экономическая. Обязательным элементом в природной составляющей экологического каркаса являются ядра, т.е. особо охраняемые территории, не подверженные антропогенному изменению. В настоящее время не существует единого мнения о том, какую площадь должны занимать ядра в экологическом каркасе. По мнению Н.Ф. Реймерса, в степи минимальный размер заповедных территорий должен составлять 20-40 тыс. га, позже методом экспертных оценок было показано соотношение 40-60 \% естественных к преобразованным ландшафтам [4]. С точки зрения ландшафтного планирования Е.Ю. Колбовский говорит об общей площади экологического каркаса отдельно взятого региона (или страны), которая должна составлять не менее 25 \% территории [5]. Подавляющее большинство экспертов считают, что для сохранения экологического баланса необходимо, чтобы доля ядер экологического каркаса от всей территории варьировала в диапазоне 20-60 \%, причем эта доля должна существенно увеличиваться с юга на север и от равнинных территорий к горным. В структуре нашего экологического каркаса ядра занимают $23 \%$ от всей площади территории, что является пороговым значением, и, следовательно, требуется выделение дополнительных объектов в систему особо охраняемых территорий как Республики Хакасия, так и Красноярского края.

\section{Заключение}

Создание полноценного ГИС-проекта требует сбора огромного объема исходных данных в области архитектуры, кадастра, экономики, статистики, природных ресурсов, инженерной и транспортной инфраструктур и многих других. Используемое программное обеспечение позволяет собрать и обработать широкий спектр разносторонней информации. ГИС-проект «Экологический каркас Южно-Минусинской котловины» может быть использован органами управления муниципальных образований Республики Хакасия и юга Красноярского края для сохранения и рационального природопользования природных ландшафтов, налаживания системы мониторинга, предотвращения чрезмерной антропогенной нагрузки на ландшафт. Составленные картосхемы могут быть применены в качестве исходной информации для исследования территорий с подобной структурой хозяйства.

\section{Список литературы}

[1] Павлова Е.В., Махрова М. Л., Ямских Г.Ю. // Вестник Хакасского государственного университета им. Н.Ф. Катанова / ред. В.П. Антонов. Абакан: Изд-во ХГУ им. Н. Ф. Катанова, 2012. Вып. 2. С. 134-138.

[2] Ямских Г.Ю. Автореф. дис. ... д-ра геогр. наук. Барнаул, 2006. 34 с.

[3] Стоящева Н.В. Экологический каркас территории и оптимизация природопользования на юге Западной Сибири (на примере Алтайского края) / ред. Б.А. Краснояров. Новосибирск: Изд-во СО РАН, 2007. $140 \mathrm{c.}$

[4] Реймерс Н.Ф. Экология (теория, законы, правила, принципы, гипотезы). М.: Россия Молодая, 1994. $367 \mathrm{c.}$

[5] Колбовский Е.Ю. Ландшафтное планирование: учеб. пособие. М.: Издательский центр «Академия», 2008. $336 \mathrm{c.}$ 